PSIKOPEDAGOGIA, Vol. 1, No. 1, Juni 2012

ISSN: 2301-6167

\title{
PERAN KECERDASAN EMOSIONAL DAN EKSPLORASI KARIER ANAK SLTP
}

\section{ROLE OF EMOTIONAL INTELLIGENCE AND CAREER EXPLORATION CHILDREN OF JUNIOR HIGH SCHOOL}

\author{
Edi Purwanta \\ Universitas Negeri Yogyakarta
}

\begin{abstract}
Abstrak
Eksplorasi karier merupakan upaya untuk memahami karakteristik diri individu dan karakteristik lingkungan karier dalam berbagai setting karier dan budaya di mana karier berada. Tujuan dari eksplorasi karier bagi anak usia SLTP tidak lain adalah untuk memilah dan memilih berbagai informasi tentang diri dan lingkunggannya sehingga anak dapat menentukan pilihan yang tepat sesuai dengan karakteristik dirinya, yang pada gilirannya is akan mencapai kemandirian. Dalam eksplorasi karier anak berhadapan dengan berbagai lingkungan karier yang berbeda baik dalam karakteristik maupun jenisnya, sehingga diperlukan kecerdasan emosional disamping kecerdasan kognitif agar anak dapat membangkitkan motivasinya, mongelola emosinya untuk lebih cerdas dalam memilih dan memakai informasi dalam membuat keputusan karier utamanya dalam kelanjutan studi ke sekolah menengah atas (SMA). Peran kecerdasan emosional dalam eksplorasi karier berhubungan dengan wilayah kecerdasan emosional, yaitu dalam mengenali emosi diri, mengelola emosi, memotivasi diri, mengenali emosi orang lain (empati), dan membina hubungan dengan orang lain.
\end{abstract}

Kata kunci: kecerdasan emosional, eksplorasi karier.

\begin{abstract}
Career exploration is an attempt to understand the characteristics of the individual and environmental characteristics of careers in a variety of careers and cultural setting in which careers are. The purpose of career exploration for junior high school age child is none other than to pick and choose a variety of information about themselves and lingkunggannya so that the child can make the right choice according to the characteristics of itself, which in turn is going to achieve independence. In a career exploration subsidiary dealing with different environments different careers both in the characteristics and type, so that the necessary emotional intelligence in addition to cognitive intelligence so that children can evoke motivation, mongelola emotions to be more intelligent in choosing and use the information in making career decisions primarily in the continuation study to the school upper secondary (high school). The role of emotional intelligence in the exploration of careers related to the area of emotional intelligence, which is in recognizing emotions, managing emotions, motivating oneself, recognizing emotions in others (empathy), and relationships with others.
\end{abstract}

Keywords: emotional intelligence, career exploration.

\section{PENDAHULUAN}

Kebijakan Departemen Pendidikan

Nasional dalam mengembangkan sekolah kejuruan diarahkan untuk menambah jumlah sekolah kejuruan dan segala fasilitas pendukungnya mulai dilaksanakan pada awal tahun 2006. Kebijakan tersebut bertujuan agar tersedia tenaga trampil dalam menghadapi perkembangan global.

Diharapkan sampai dengan tahun 2020, proporsi SMU dan SMK antara 30 dibanding 70 (Kedaulatan Rakyat, 2008). Keadaan ini mendorong sebagian besar siswa SLTP untuk melakukan pilihan karier dalam 
bentuk pilihan kelanjutan studi lebih awal, yang semestinya terjadi pada tingkat SMU.

Dewasa ini ada sekitar 120 program kejuruan di tingkat SMK. Masing-masing program tersebut memiliki karakteristik yang berbeda. Masing-masing karakteristik menuntut kesiapan kemampuan yang dipersyaratkan di antara program tersebut. Ketepatan siswa dalam mengkaji untuk memilah dan memilih program kelanjutan Studi sesuai dengan minat dan kemampuannya merupakan tuntutan yang perlu difasilitasi pada mereka. Banyaknya pilihan program di SMK ini merupakan isyarat untuk melakukan eksplorasi yang cerdas baik secara kognitif maupun secara emosional.

Sementara dalam konteks teori perkembangan karier siswa SLTP berada pada fase tentatif (Super, 1984 dalam Brown, D., Brooks, L. , and Associates (Eds.), 1984). Dalam fase tentatif ada empat tahap, yaitu tahap minat, tahap kapasitas, tahap nilai, dan tahap transisi. Dalam tahap minat, anak mulai mengembangkan karier mereka berdasarkan minat anak. Pilihan karier akan berubah berdasarkan perubahan minat anak saat itu. Dalam tahap kapasitas, anak mulai mengembangkan kemampuannya sesuai dengan minat dan pilihan kariernya. Anak mulai menekuni beberapa kemampuan yang mendukung karier yang dipilihnya. Dalam tahap nilai, anak mulai mengembangkan nilai yang ada pada dirinya, pilihan karier sesuai dengan nilai yang berkembang dalam dirinya. Dalam tahap transisi anak mulai mengarahkan aspirasi karier sesuai dengan minat, kapasitas, dan nilai yang bersifat tentatif.
Proses pilihan karier diawali dengan kegiatan orientasi dan eksplorasi karier yang terjadi pada fase tentative pada usia SLTP. Eksplorasi karier yang komprehensif akan mendukung pemahaman diri, pemahaman lingkungan karier, dan keterampilan dalam memadukan antar keduanya. Tujuan eksplorasi karier adalah mengembangkan pemahaman secara luas terhadap karier yang tersedia, variasi karakteristik pekerja, relevansi mata pelajaran dengan dunia kerja, dan evaluasi diri (Studer, J.R. 2005).

Eksplorasi karier yang dilakukan secara dini akan menimbulkan permasalahan bagi mereka. Mereka hams mampu menggunakan kemampuan kognitif dan emosionalnya untuk menggali seluruh informasi yang ada pada dirinya dan informasi yang ada di luar dirinya, terutama dalam kaitannya dengan keluasan dan kedalaman informasi pilihan program di SMK. Bagi anak yang mampu mempersiapkan diri dengan baik, mereka akan mulai melakukan eksplorasi dengan cermat baik pada potensi dirinya maupun pada program di SMK yang akan dipilih. Bagi mereka yang kurang mampu, mereka akan mengalami kesulitan dalam mengelola diri, dan mengarahkan diri sesuai dengan minat, kapasitas, dan nilai yang ada pada dirinya. Untuk itu semua, mereka memerlukan kemauan yang kuat, motivasi yang tinggi dalam mengeksplorasi diri dan pilihan program studinya.

Terkendalanya anak dalam melakukan eksplorasi karier tidak hanya disebabkan karena rendahnya kemampuan mereka, tetapi juga karena kemauan dan motivasi mereka dan 
pengelolaan emosi mereka, serta cara mereka membina hubungan dengan orangtua, para guru, konselor, dan orang lain yang dianggap sebagai sumber informasi, atau bahkan mungkin sikap "pasrah" mereka pada orangtua. Kondisi ini sebenarnya merupakan gejala dari kecerdasan emosional (Goleman, 2006). Lebih lanjut, Goleman (1996) mengatakan bahwa kecerdasan emosional dapat memotivasi individu untuk melakukan tindakan berdasarkan rencana seketika untuk mengatasi masalah yang dihadapi oleh individu termasuk dalam eksplorasi karier.

Sehubungan dengan permasalahan tersebut di atas, sajian akan mengkaji peran kecerdasan emosional dalam eksplorasi karier anak SLTP. Untuk mengkaji masalah tersebut berikut ini akan dibahas tentang(a) gambaran eksplorasi karier anak SLTP; (b)gambaran konsep kecerdasan emosional; dan (c) peran kecerdasan emosional dalam eksplorasi karier anak SLTP.

\section{PEMBAHASAN}

\section{Gambaran Eksplorasi Karier Anak SLTP}

Bimbingan dan konseling sekolah merupakan aktivitas layanan yang bertujuan untuk mernfasilitasi siswa dalam mencapai kemandirian secara akademik, vokasional, dan social-personal. Tujuan pelayanan bimbingan ialah agar konseli dapat:

a. Merencanakan kegiatan penyelesaian studi, perkembangan karir serta kehidupannya di masa yang akan datang.

b. Mengembangkan seluruh potensi dan kekuatan yang dimilikinya seoptimal mungkin. c. Menyesuaikan diri dengan lingkungan pendidikan, lingkungan masyarakat serta lingkungan kerjanya.

d. Mengatasi hambatan dan kesulitan yang dihadapi dalam studi, penyesuaian dengan lingkungan pendidikan, masyarakat, maupun lingkungan kerja.

Untuk mencapai tujuan-tujuan tersebut, mereka harus mendapatkan kesempatan untuk:

a. Mengenal dan memahami potensi, kekuatan, dan tugas-tugas perkembangannya.

b. Mengenal dan memahami potensi atau peluang yang ada di lingkungannya.

c. Mengenal dan menentukan tujuan dan rencana hidupnya serta rencana pencapaian tujuan tersebut.

d. Memahami dan mengatasi kesulitankesulitan sendiri.

e. Menggunakan kemampuannya untuk kcpentingan dirinya, kepentingan lembaga tempat bckerja dan masyarakat.

f. Menyesuaikan diri dengan keadaan dan tuntutan diri lingkungannya.

g. Mengembangkan segala potensi dan kekuatan yang dimilikinya secara optimal.

Secara khusus bimbingan dan konseling bertujuan untuk membantu konseli agar dapat mencapai tugas-tugas perkembangannya yang meliputi aspek pribadi-sosial, belajar (akademik), dan karir. (Penataan Pendidikan Preofesional Konselor dan Layanan Bimbingan dan Konseling dalam Jalur Pendidikan Formal, 2007:pp.197 — 200). 
Lebih khusus lagi dalam kaitannya dengan dengan bimbingan karier, tujuan bimbingan dan konseling di sekolah adalah siswa:

a. Memiliki pemahaman diri (kemampuan, minat dan kepribadian) yang terkait dengan pekerjaan.

b. Memiliki pengetahuan mengenai dunia kerja dan informasi karir yang menunjang kematangan kompetensi karir.

c. Memiliki sikap positif terhadap dunia kerja. Dalam arti mau bekerja dalam bidang pekerjaan apapun, tanpa merasa rendah diri, asal bermakna bagi dirinya, dan sesuai dengan norma agama.

d. Memahami relevansi kompetensi belajar (kemampuan menguasai pelajaran) dengan persyaratan keahlian atau keterampilan bidang pekerjaan yang menjadi cita-cita karirnya masa depan.

e. Memiliki kemampuan untuk membentuk identitas karir, dengan cara mengenali ciriciri pekerjaan, kemampuan (persyaratan) yang dituntut, lingkungan sosio-psikologis pekerjaan, prospek kerja, dan kesejahteraan kerja.

f. Memiliki kemampuan merencanakan masa depan, yaitu merancang kehidupan secara rasional untuk memperoleh peran-peran yang sesuai dengan minat, kemampuan, dan kondisi kehidupan sosial ekonomi.

g. Dapat membentuk pola-pola karir, yaitu kecenderungan arah karir. Apabila seorang konseli bereita-cita menjadi seorang guru, maka dia senantiasa hams mengarahkan dirinya kepada kegiatan-kegiatan yang relevan dengan karir keguruan tersebut. h. Mengenal keterampilan, kemampuan dan minat. Keberhasilan atau kenyamanan dalam suatu karir amat dipengaruhi oleh kemampuan dan minat yang dimiliki. Oleh karena itu, maka setiap orang perlu memahami kemampuan dan minatnya, dalam bidang pekerjaan apa dia mampu, dan apakah dia berminat terhadap pekerjaan tersebut; dan.

i. Memiliki kemampuan atau kematangan untuk mengambil keputusan karir.

Dalam kaitannya dengan bimbingan dan konseling karier langkah awal yang dilakukan oleh siswa SLTP adalah melakukan eksplorasi karier. Eksplorasi karier menurut Blustein (1993) dalam Wall, J.E. (1994) adalah aktivitas yang berupaya untuk meningkatkan pemahaman dirinya dan dunia luar (lingkungannya). Dalam tataran praktis untuk memperoleh informasi tentang diri anak yang berkaitan dengan bakat, minat, dan nilai serta berupaya untuk menyelaraskan (to match) tuntutan karakteristik spesifik dari karier yang dipilihnya. Dalam konteks ini karier tersebut adalah pilihan program kelanjutan studi. Pengertian yang relatif sama dinyatakan oleh Maria Do Ceu Taveira, et.al. (1998) bahwa eksplorasi karier dilakukan tidak hanya pada usia adolesen (saat mahasiswa) tetapi sejak is berada pada masa kanak-kanak dan mulai intensif sejak mereka berada pada remaja awal. Eksplorasi karier merupakan aktivitas yang bertujuan untuk memperoleh pengetahuan tentang diri dan lingkungan sekitar yang mendorong individu untuk meningkatkan perkembangan kariernya: Dari kedua pengertian tersebut bahwa eksplorasi 
karier terjadi dalam kehidupan perkembangan karier individu; eksplorasi karier sebagai upaya menggali potensi, minat, nilai, dan aspirasi diri serta karakteristik karier dalam berbagai perspektif.

Tujuan eksplorasi karier adalah mengembangkan pemahaman secara luas terhadap karier yang tersedia, variasi karakteristik pekerja, relevansi mata pelajaran dengan dunia kerja, dan evaluasi diri (Studer, J.R. 2005:185). Pada tujuan yang lebih spesifik, Holland dan Brown menyatakan bahwa tujuan eksplorasi karier adalah membantu konseli untuk mengidentifikasi jenis karier termasuk karakteristik pekerjanya untuk memperoleh congruence dengan karakteristik pribadinya (Holland.1997; Brown. 2007. p: 37)

Ada berbagai strategi yang dapat dilakukan dalam melaksanakan eksplorasi karier. Strategi tersebut adalah fantasi karier, magang sementara (paroh karier), karya wisata, karier riset, interviu karier, proyek interprenuer, portpolio karier, assesmen diri, penemuan diri, integrated curriculum, paket eksplorasi karier, menghadirkan orangtua dalam kelas, dinamika kelompok, latihan kepemimpinan, latihan pemecahan masalah, pengambilan keputusan, dan keterampilan komunikasi (Studer, J.R. 2005:185).

\section{Konsep Kecerdasan Majemuk}

Kajian tentang kecerdasan emosional memang merupakan kajian baru, berbeda dengan kecerdasan kognitif (IQ) yang penelitiannya telah berumur hampir seratus tahun teradap ratusan ribu orang dari berbagai budaya yang berbeda. Walaupun sebagai kajian yang masih relative barn, data menunjukkan bahwa kecerdasan emosional dapat sama ampuhnya dan bahkan lebih ampuh dari IQ (Goleman, 1996; Shapiro, 1997). Istilah kecerdasan emosional pertama kali dilontarkan pada tahun 1990 oleh Peter Salovey dari Harvard University dan John Mayer dari Universitas of New Hampshire untuk menerangkan kualitas-kualitas emosional yang tampaknya penting bagi keberhasilan. Kualitas-kualitas itu antara lain adalah empati, mengungkapkan dan memahami perasaan, pengendalian amarah, kemandirian, kemampuan menyesuaikan diri, disukai, kemampuan memecahkan masalah antar pribadi, ketekunan, kesetiakawanan, kemarahan, dan sikap hormat (Solovey dan Mayer, 1990). Goleman (1996) dalam bukunya Emotional Intelligence mengemukakan bahwa kecerdasan emosional merupakan kemampuan untuk memotivasi diri sendiri dan bertahan menghadapi frustrasi; mengendalikan dorongan hati dan tidak berlebih-lebihan dalam kesenangan; mengatur suasana hati, dan menjaga agar bebas dari stress tidak melumpuhkan kemampuan berpikir; berempati dan berdoa. Pendapat senada dikemukakan oleh Cooper (1997), bahwa kecerdasan emosional adalah kemampuan merasakan, memahami dan secara efektif menerapkan daya dan kepekaan emosi sebagai sumber energy, informasi, koneksi dan pengaruh manusiawi. Kecerdasan emosional sejalan dengan apa yang disebut oleh Gardner 
(2006) dengan kecerdasan antar dan inter pribadi. Kecerdasan antar dan inter pribadi merupaka kecerdasan yang memungkinkan seseorang memahami dan bekerja dengan orang lain dan kecerdasan yang memungkinkan seseorang memahami dan bekerja dengan dirinya sendiri (Gardner, 2006). Dari pengertian tersebut dapat disimpulkan bahwa kecerdasan emosional adalah kemampuan individu dalam belajar mengakui dan menghargai perasaan yang ada pada diri sendiri dan orang lain, menanggapinya dengan tepat, maupun menerapkan informasi yang efektif serta menyalurkan energi emosi dalam kehidupan dan pekerjaan sehari-hari.

Salovey dalam Goleman (1996) membagi wilayah kecerdasan emosional itu menjadi lima wilayah utama, yaitu:

a. Mengenali emosi diri. Mengenali emosi diri adalah kemampuan untuk mencermati dan mengenali perasaan sendiri yang sesungguhnya. Kesadaran diri mengenali perasaan sewaktu itu terjadi merupakan kecerdasan emosional. Orang yang memiliki keyakinan yang lebih tentang perasaannya adalah pilot yang andal bagi kehidupan mereka, karena mempunyai kepekaan lebih tinggi akan perasaan mereka yang sesungguhnya atas pengambilan keputusan-keputusan dalam masalah yang dilaluinya.

b. Mengelola emosi. Mengelola emosi adalah kemampuan untuk menangani perasaan agar perasaan dapat terungkap. Orangorang yang buruk kemampuannya dalam keterampilan mengelola emosi akan terus menerus bertarung melawan perasaan murung, sementara mereka yang pintar dapat bangkit kembali dengan jauh lebih cepat dari kemerosotan dan kejatuhan dalam kehidupan.

c. Memotivasi diri sendiri. Memotivasi diri sendiri adalah menata emosi sebagai alat untuk mencapai tujuan adalah hal yang penting untuk memotivasi diri sendiri dan menguasai diri sendiri, dan untuk berkreasi. Orang-orang yang memiliki keterampilan memotivasi diri cenderung jauh lebih produktif dan efektif dalam melalukan pekerjaan apapun.

d. Mengenali emosi orang lain. Mengenali emosi orang lain merupakan kemampuan mengenal dan merasakan apa yang dirasakan orang lain (empati). Empati merupakan kemampuan yang bergantung pada kesadaran emosional, dan empati juga merupakan syarat dalaiii keterampilan bergaul. Orang yang empatinya tinggi mampu menangkap sinyal-sinyal social yang tersembunyi yang mengisyaratkan apa-apa yang dibutuhkan atau dikehendaki orang lain.

e. Membina hubungan. Membina hubungan merupakan seni dan keterampilan dalam mengelola emosi orang lain. Keterampilan ini merupakan keterampilan yang menunjang popularitas, kepemimpinan, dan keberhasilan pribadi. Orang-orang hebat dalam keterampilan ini akan sukses dalam bidang apapun yang mengandalkan pergaulan yang mulus dengan orang lain;mereka adalah bintang-bintang pergaulan yang hebat. 


\section{Peran Kecerdasan Emosional dalam Eksplorasi Karier}

Setelah mengkaji dua kajian di atas dapat disimpulkan bahwa kecerdasan emosional mempunyai peran yang penting dalam semua lapangan kehidupan. Orang yang cerdas secara emosional ia akan terampil dalam memotivasi diri, mengelola diri dan menjalin hubungan dengan orang lain dalam rangka mencari informasi yang sesuai dengan keadaan dirinya. Kecakapan emosional ini berkenaan dengan kemampuan seseorang untuk memahami serta menanggapi secara tepat perasaan orang lain, serta dalam memelihara hubungan baik dengan orang lain, yang secara keseluruhan juga dinamakan seni bergaul (social arts) (Raka Joni, 2008). Memperhatikan kelima wilayah kerja kecerdasan emosional Bari Goleman, maka peran kecerdasan emosional dalam eksplorasi karier adalah sebagai berikut:

a. Mengenali emosi diri. Mengenal emosi diri merupakan akar dari kesadaran diri (selfawareness), yaitu kemampuan untuk mengenal diri sendiri. Dalam kaitannya dengan eksplorasi karier, mengenal diri sendiri lebih diarahkan pada mengenal bakat, minat, nilai, dan kepribadiannya. Pemahaman yang mendalam tentang dirinya akan berdampak ketepatan mereka dalam memilih informasi yang pada gilirannya akan memperoleh kesesuaian dalam mengarahkan aspirasi dan pilihan kariemya.

b. Mengelola emosi. Mengelola emosi berkaitan erat dengan kemampuan mengatur perasaan sendiri. Ketepatan mengelola emosi dapat dijadikan motivasi positif dalam mengelola rasa cemas, takut, marak, khawatir dalam menghadapi perubahan karier di saat ini. Perubahan lingkungan dan budaya yang cepat sebagai konsekuensi dari arus global mendorong individu untuk terus melakukan eksplorasi, khususnya pada bidang karier, sehingga kelak mereka akan tepat dalam memilih karier. Pilihan bukan sekedar ikut-ikutan atau paksaan orang tua, tetapi sudah dengan pertimbangan diri yang mantap.

c. Memotivasi diri sendiri. Memotivasi diri berkaitan erat dengan kemandirian. Kemandirian akan mendorong individu untuk memperoleh kepercayaan diri (selfreliance) dan menumbuhkan motif berprestasi (need for achievement). Kemandirian akan memotivasi individu untuk melakukan eksplorasi yang luas dan teliti sehingga individu tersebut akan tepat dalam membuat pilihan

d. Mengenali emosi orang lain (empati). Kemampuan berempati merupakan akar dari mengenali emosi orang lain. Dalam eksplorasi karier kemampuan berempati terhadap orang-orang yang berada dalam kelompok lingkungan karier akan mempermudah individu untuk mengenali karakteristik lingkungan kariemya, dan bahkan ia ikut merasakan mana kala ia bekerja di karier tersebut. Misalnya berempati sebagai hakim; ia merasakan betapa arifnya seorang hakim malam mengambil keputusan untuk mencapai keadilan; berempati sebagai petani 4 
merasakan jerh payah mereka untuk mencukupi kebutuhan pangan; berempati sebagai enterprenuer merasakan bagaimana bila ia ditolak atau meyakinkan pendapatnya kepada orang lain.

e. Membina hubungan. Membina hubungan merupakan akar dari keterampilan social. Dalam melakukan eksplorasi karier individu akan selalu berhadapan dengan Berbagai berbagai orang dalam lingkungan karier yang berbeda satu dengan yang lain. Keberhasilan individu dalam membina hubungan dengan orang-orang yang berada dalam lingkungan dan budaya karier yang berbeda akan membantu untuk indivu dalam memahami keragaman yang terjadi. Untuk itu diperlukan tenggang rasa, sikap hormat, dan menghargai kegaraman tersebut. Hal ini merupakan bagian dari kecerdasan emosional.

\section{KESIMPULAN}

a. Eksplorasi karier merupakan bagian yang tak terpisahkan dari perkembangan karier individu. Eksplorasi karier merupakan upaya untuk memahami karakteristik diri individu dan karakteristik lingkungan karier dalam berbagai setting karier dan budaya di mana karier berada. Tujuan dari eksplorasi karier tidak lain adalah untuk memilih dan memilih berbagai informasi yang tepat sehingga anak dapat menentukan pilihan yang tepat sesuai dengan karakteristik dirinya, yang pada gilirannya is akan mencapai kemandirian.

b. Dalam eksplorasi karier anak berhadapan dengan berbagai lingkungan karier yang berbeda baik dalam karakteristik maupun jenisnya, sehingga diperlukan kecerdasan emosional disamping kecerdasan kognitif agar anak dapat membangkitkan motivasinya, mengelola emosinya untuk lebih cerdas dalam memilih dan memakai inforrnasi dalam membual keputusan karier.

c. Peran kecerdasan emosional dalam eksplorasi karier berhubungan dengan wilayah kecerdasan emosional, yaitu dalam mengenali emosi diri, mengelola emosi, memotivasi diri, mengenali emosi orang lain (empati), dan membina hubungan dengan orang lain.

\section{REFERENSI}

Brown, Duane. (2007). Career information, career counseling, and career development. 9th.ed. Boston: Pearson Education, Inc.

Brown, D., Brooks, L. , and Associates (Eds.),(1984). Career choice and development. 2nd.ed. San Francisco: Jossey-Bass.

Depdiknas.(2007). Penataan Pendidikan Profesional Konselor dan Layanan Bimbingan dan Konseling dalam Jalur Pendidikan Formal

Gardner, H. (2006). Multiple Intelligences: New Horizons. New York: Basic Books

Goleman, Daniel. 1996. Emotional Intelligence. New York: Bantam 
Books

Holland, J.L. (1997). Making vocational choices. ri.ed. Englewood Cliffs, New York: Prentice-Hall.

Maria Do Ceu Taveira. (et.al). (1998). "Individual characteristics and career explorations". Bristish journal of guidance and counseling. Feb. (1998); 26:1. ProQuest Education Journals

Raka Joni, T. (2008). Resureksi Pendidikan Profesional Guru. Malang: LP3 UM Cakrawala Indonesia

Salovey, Peter,. Mayer, J.D. (1990). "Imagination, Cognition, and Personality". Emotional Intelligence. 9 (1990). Pp. 185 211

Shapiro, Lawrence E. (1997). How to Raise A Child with A High EQ: A Parents' Guide to Emotional Intelligence. New York: Harper Collins Publishers, Inc.

Shapiro, L. E. (2001). Mengajarkan Emosional Intelligence (Alih bahasa Alex Tri Kantj ono). Jakarta: Gramedia Pustaka Utama profesional school counselor: an advocate for student. Belmont, CA: Thomson Brooks/Cole

Wall, Janet E. (1994). "An example of assessment's role in career exploration". Journal of counseling and development: JCD; July 1994; 72. 6; ProQuest Education Journals 